\title{
Partisipasi Masyarakat Lokal Desa Angseri Dalam Pengelolaan Daya Tarik Wisata Air Panas Angseri, Kecamatan Baturiti, Tabanan
}

GedeMahendra Saputra a, 1, Saptono Nugroho a, 2

1mahendrasaputra25@gmail.com, 2saptono_nugroho@unud.ac.id

a Program Studi S1 Destinasi Pariwisata, Fakultas Pariwisata,Universitas Udayana, Jl. Dr. R. Goris, Denpasar, Bali 80232 Indonesia

\section{Abstract}

Angseri village is located in Baturiti subdistrict, Tabanan regency, Bali. Angseri village has Angseri Hot Springs as a tourist attraction. This tourist attraction has a special characteristic than another hot springs tourist attraction. The special characteristic of this hot springs is in the middle of bamboo forest. The management of this hot springs started in 2007 until now and this management still running well with many involved party in it. The research that will be done is about how is the actual condition of Angseri hot springs reviewed on tourism product component and how is the pattern of participation in management of Angseri hot springs in Angseri village which the management is managed by the local community itself.

The research method used is qualitative descriptive with in-depth interview, observation, documentation, and literature study. The data sources are obtained from primary and secondary data. The theory and concept used are concept of attraction, concept of management, concept of tourism product component, and theory of participation typology in management.

The actual condition is reviewed from tourism product component located in Angseri hot springs which is an attraction that take benefit from natural potential in the form of hot springs, an adequate access, feasible infrastructures, and the completeness of supporting facilities. In the participation typology of local community in management of Angseri hot springs, there were well organization and management structure and the participation of local community which belongs to pushed participation. In this case, the local community is given socialization by Tourism Department in the beginning of planning Angseri hot springs tourist attraction.

Keywords: Participan, Management,Product Component, Angseri Hot Springs

\section{PENDAHULUAN}

Desa Angseri berada di Kecamatan Baturiti, Kabupaten Tabanan. Desa Angeri memiliki potensi alam yang unik karena keadaan alam yang masih asri diimbangi dengan budaya masyarakat sekitar yang sebagian besar merupakan petani serta arsitektur bangunan rumah yang masih tradisional. Berdasarkan hasil observasi pendahuluan, Desa Angseri yang memiliki tiga banjar tentunya memiliki potensi di masing- masing banjar tersebut. Banjar pertama adalah Banjar Tegeh, Banjar kedua adalah Banjar Angseri dan banjar ketiga yaitu Banjar Munduk Lumbung. Ketiga banjar ini memiliki nilai sejarah awal terbentuknya banjar-banjar tersebut yang menarik untuk diketahui.

Desa Angseri memiliki Daya Tarik Wisata unggulan berupa sumber air panas alami dan air terjun, kedua daya tarik ini berada pada satu tempat yaitu di Daya Tarik Wisata Air Panas Angseri. Untuk mewujudkan pembangunan pariwisata yang berkelanjutan, masyarakat lokal juga turut berpartisipasi ke dalam pengelolaan daya tarik wisata ini dengan membentuk sebuah kelompok pengelola yang berasal dari warga ketiga banjar di Desa Angseri tersebut. Daya Tarik Wisata Air Panas Angseri kini sudah berjalan selama 9 tahun, partisipasi dari masyarakat lokal sangat terlihat dari segi pengelolaan dalam mengolah sumber daya baik itu alam maupun sosialnya dengan terus berkembangnya dari segi infrastruktur jalan dan penunjuk arah menuju daya tarik wisata, fasilitas penunjang daya tarik dan peningkatan ekonomi masyarakatnya.

Berdasarkan pemaparan diatas maka fokus penelitian yang akan diteliti adalah kondisi aktual Daya Tarik Wisata Air Panas Angseri ditinjau dari komponen produk pariwisata dan bagaimana bentuk partisipasi dalam pengelolaan Daya Tarik Wisata Air Panas Angseri yang terdapat di Desa Wisata Angseri yang pengelolaan destinasi ini dikelola langsung oleh masyarakatnya dengan tujuan untuk mengetahui kondisi aktual dan tipologi masyarakat lokal Desa Angseri dalam mengelola Daya Tarik Wisata Air Panas Angseri. 


\section{TINIAUAN PUSTAKA}

Terdapat tiga telaah hasil penelitian sebelumnya yang mengacu kepada penelitian ini. Hasil penelitian yang pertama dilakukan oleh Nurdiyanto (2015) yang berjudul "Partisipasi Masyarakat dalam Pengembangan Desa Wisata pada Desa Wisata Bleberan, Kecamatan Playen, Kabupaten Gunung Kidul" yang terkait dengan partisipasi masyarakat, telaah penelitian yang kedua yaitu Wicaksono (2013) yang berjudul "Efektivitas Program Penataan dan Pengelolaan Objek Wisata" dengan studi kasus Pariwisata Bahari dan Permandian So'Do di Kabupaten Mamuju yang terkait dengan pengelolaan Daya Tarik Wisata dan penelitian yang terakhir yaitu Sudinata dan Budiarta (2013) dengan judul Strategi Pengembangan Daya Tarik Ekowisata Berbasis Kerakyatan di Desa Cau Belayu Kecamatan Marga Kabupaten Tabanan yang mengacu pada lokasi penelitian.

Konsep dan Teori yang digunakan dalam penelitian ini adalah konsep daya tarik oleh Yoeti (1985) yaitu segala sesuatu yang menjadi daya tarik bagi seseorang saat mengunjungi daerah tertentu. Daya taruk yang dimaksud adalah keberadaan air panas yang mengandung belerang dan bersumber dari Gunung Batukaru, konsep produk wisata Sunaryo (2013) yaitu potensi yang dimiliki oleh daya tarik wisata merupakan modal dalam pengembangan suatu destinasi pariwisata, selain faktor-faktor pendukung lainnya. Pengembangan destinasi pariwisata minimal mencakup komponen-komponen utama yaitu atraksi, aksesibilitas, amenitas dan fasilitas pendukung. Konsep ini digunakan untuk menguraikan kondisi eksisting dari Daya Tarik Wisata Air Panas Angseri, konsep manajemen pengelolaan dari James A.F. Stoner (2006) yaitu proses perencanaan, pengorganisasian, kepemimpinan dan pengawasan upaya atau usaha-usaha anggota organisasi dan penggunaan sumber daya organisasi untuk mencapai tujuan organists yang telah ditetapkan. Tahap-tahap dari pernyataan tadi digunakan untuk mengetahui proses perkembangan dari berjalannya kegiatan pariwisata di Daya Tarik Wisata Air Panas Angseri, dan menggunakan teori analisis Typology of Participation (Tosun, 2006) yang berisi karakteristik dan bentuk partisipasi seperti partisipasi spontan, terdorong dan paksaan. Bentuk-bentuk partisipasi ini digunakan untuk mengetahui partisipasi yang terjadi di Daya Tarik Wisata Angseri.

\section{METODE}

Sumber data yang digunakan dalam penelitian ini adalah Data Primer yang dapat diperoleh melalui observasi untuk mengetahui bentuk partisipasi masyarakat lokal dalam pengelolaan Daya Tarik Wisata Air Panas Angseri, serta wawancara yang akan dilakukan dengan informan yang terlibat dalam pengelolaan Daya Tarik Wisata Air Panas Angseri dan Data Sekunder. Data Sekunder yang dimaksud dalam penelitian ini berupa dokumen atau arsip mengenai profil Daya Tarik Wisata Air Panas Angseri, jumlah kunjungan wisatawan ke Kabupaten Tabanan dan Daya Tarik Wisata serta jumlah pegawai atau staff yang bekerja di Daya Tarik Wisata. Selain itu data juga di dapat dari buku-buku, internet dan artikel yang terkait dengan penelitian partisipasi masyarakat

Teknik pengumpulan data dalam penelitian ini adalah observasi yaitu teknik pengumpulan data dengan mengadakan pengamatan langsung ke lokasi penelitian untuk memperoleh gambaran yang jelas mengenai partisipasi masyarakat Desa Angseri di Daya Tarik Air Panas Angseri, wawancara yaitu cara mengumpulkan data dengan mengadakan tanya jawab secara langsung kepada masyarakat Desa Angseri dan pengelola Daya Tarik Wisata Angseri, dokumentasi yaitu teknik pengumpulan data yang digunakan untuk mengambil gambar atau foto kegiatan pariwisata dan suasana di Daya Tarik Wisata Air Panas Angseri, dan studi kepustakaan yaitu literatur-literatur, jurnal-jurnal dan catatancatatan yang berkaitan dengan lokasil penelitian, partisipasi, manajemen pengelolaan dan pariwisata berbasis masyarakat di Desa Angseri.

Teknik analisis data yang digunakan menurut Bogdan dan Biklen dalam Moleong (2012) analisis data kualitatif merupakan upaya yang dilakukan dengan jalan bekerja dengan data, mengorganisasi data, memilahmilah menjadi satuan yang dapat dikelola, mencari dan menemukan pola, menemukan apa yang penting, apa yang dipelajari dan 
memutuskan apa yang dapat diceritakan kepada orang lain. Data yang ada pada penelitian ini lebih banyak berupa deskriptif dan menguraikan secara rinci hasil informasi dari fakta-fakta yang diperoleh saat observasi di lapangan serta uraian oleh informan di Daya Tarik Wisata Air Panas Angseri.

\section{HASIL DAN PEMBAHASAN}

\subsection{Gambaran umum Desa Angseri.}

Luas wilayah Desa Angseri, 758,160 ha secara administratif Desa Angseri terbagi atas tiga banjar yang meliputi banjar Banjar Tegeh, Banjar Angseri, Banjar Munduk Lumbung. Penggunaan lahan di wilayah Desa Angseri, sekarang dipilah menjadi daerah pemukiman 38.22 ha, tanah sawah 226.545 Ha perkebunan/tegalan 642.16 ha, hutan 10,237 ha dan perikanan dan peternakan nol ha serta penggunaan lain-lain (fasilitas umum, pura, setra, jalan, lapangan dan sebagainya) seluas 20 ha(Sumber:http://baturiti.tabanankab.go.id/pr ofil-desa/desa-angseri). Desa Angseri memiliki jalan sepanjang tujuh $\mathrm{km}$, dengan rincian: jalan nasional nol $\mathrm{km}$, jalan provinsi tiga $\mathrm{km}$, jalan kabupaten empat km.

Daya Tarik Wisata Air Panas Angseri sudah terbentuk pada tanggal 12 Oktober 2007 dan terletak di Banjar Munduk Lumbung, Desa Angseri, Kecamatan Baturiti, Kabupaten Tabanan. Lokasinya sekitar $40 \mathrm{~km}$ dari Kota Denpasar atau $20 \mathrm{~km}$ dari Kota Tabanan. Dari Kota Denpasar melewati jalan utama menuju Bedugul untuk sampai ke Daya Tarik Wisata ini. Selain itu adapun rute lain yang dapat ditempuh, yaitu dari Penebel melalui Jatiluwih ke arah timur laut, dimana rute ini sedikit lebih sulit dibandingkan rute melewati Bedugul. Daya Tarik Wisata Air Panas Angseri menjadi tempat wisata favorit belakangan ini, tidak hanya bagi masyarakat lokal, tetapi wisatawan asing juga menyukainya karena suasana masih tergolong asri. Arealnya menghijau karena kaya akan pohon-pohonan, juga alam persawahan yang bertingkat. Berwisata ke Air Panas Angseri selain untuk refreshing sambil berobat. Suasana saat baru memasuki daya tarik wisata ini sangat sepi namun karena itulah daya tarik wisata ini memberi kesan yang damai dan tentram bagi wisatawan, setelah membayar tiket seharga 7.000 rupiah, 5.000 untuk tiket kolam besar dan 2.000 untuk biaya parkir. Untuk warga negara asing dikenakan biaya sebesar 35.000 rupiah.

Akses menuju spot air panas dilanjutkan melalui jalan setapak yang cukup sempit, lembab dan berlumut, pengunjung harus berhati-hati ketika melewati rute ini karena terkadang beberapa hewan dari hutan seperti ular dan biawak melintas disini. Selanjutnya setelah melewati jalan setapak kita akan bertemu persimpangan yaitu lurus dan ke kanan, jika kearah lurus maka akan sampai di Pura Puncak Tinggah dimana Pura ini memang terletak di dalam daya tarik wisata ini, jika ke kanan kita akan menjumpai restoran dan beberapa warung yang dikelola oleh masyarakat sekitar Desa Angseri, setelah itu maka akan sampai di spot air panas dimana kita bisa menyerahkan tiket yang diberikan diawal tadi untuk diperiksa. Disini kita bisa memilih apakah akan berendam di kolam terbuka atau berendam di dalam bilik. Jika ingin di kolam terbuka maka pengunjung akan dipersilahkan langsung untuk mandi atau berendam tanpa dikenakan biaya.

Jika tidak suka dengan keramaian dan ingin merasakan suasana yang sepi maka bisa mandi atau berendam di dalam bilik yang disediakan dan dikenakan biaya tambahan sebesar 15.000 rupiah per-30 menit saja, untuk kolam terbuka terbagi menjadi dua yaitu kolam untuk orang dewasa dan anak-anak. bilik yang disediakan pada awalnya hanya 4 bilik pemandian namun seiring permintaan dan mulai berkembangnya daya tarik wisata ini maka ditambah hingga saat ini bertambah menjadi 10 bilik kamar, 9 untuk bilik yang biasa dan 1 bilik spesial untuk wisatawan yang menginginkan suasana yang lebih bersifat pribadi dan dikenakan biaya yang lebih mahal yaitu 50.000 rupiah. Bilik ini dulunya direncanakan sebagai homestay namun tidak terlalu efektif jadi difungsikan sebagai bilik pribadi. Bilik ini terletak diluar area bilik-bilik dan kolam pemandian. Hal ini membuat suasananya lebih sepi karena berhadapan langsung dengan alam.

Sumber dari air panas di daya tarik wisata ini berasal dari Gunung Batukaru dan panas airnya berkisar $24^{\circ} \mathrm{C}-28^{\circ} \mathrm{C}$. Air panas yang dialirkan dari Gunung Batukaru ini mengandung belerang yang bermanfaat untuk menyembuhkan penyakit kulit seperti gatalgatal dan manfaat lainnya untuk 
merelaksasikan tubuh sekaligus melepas stress. Daya tarik wisata ini dibuka setiap hari, mulai pukul 09.00 WITA hingga 17.00 WITA.

\subsection{Kondisi Aktual Daya Tarik Wisata Air Panas Angseri}

Pengembangan Daya Tarik Wisata Air Panas Angseri tak lepas dari adanya pengelolaan yang tepat, pengembangan ini mencakup komponen-komponen penting dialamnya seperti terdapatnya atraksi wisata, akses menuju daya tarik, fasilitas-fasilitas pendukung dan sarana prasarana yang memadai seperti berikut.

\subsubsection{Atraksi (Attraction)}

Atraksi yang di maksud yaitu air panas yang mengandung belerang. Sumber air panas dengan suhu berkisar $24^{\circ} \mathrm{C}-28^{\circ} \mathrm{C}$ sebagai daya tarik utama yang berasal dari Gunung Batukaru dengan segala manfaatnya sebagai penyembuh penyakit kulit seperti gatal-gatal atau sekedar bersantai sambil menikmati panorama alam dan suasana yang tenang. Pada awalnya air panas ini hanyalah sebuah pemandian umum untuk masyarakat lokal namun seiring berjalan waktu berkembanglah menjadi sebuah daya tarik wisata. Atraksi lainnya yaitu Pemandangan Alam. Selain air panas sebagai atraksi utama, pemandangan alam yang masih asri dengan nuansa hijau disekitar daya tarik wisata ini menambah kesan yang nyaman. Menyusuri rimbunnya hutan bambu kemudian melewati areal persawahan sebelum sampai ke spot air panas menambah pengalaman yang menarik bagi wisatawan.

Terdapat 3 hal yang menjadi kunci kenapa pemandian air panas ini cocok menjadi sebuah daya tarik yaitu letaknya menyatu dengan alam, tidak seperti daya tarik wisata yang sama-sama menjadikan air panas sebagai daya tarik utamanya Air Panas Angseri memiliki konsep yang khas yaitu menyatu dengan alam yaitu berada disekitar hutan bambu, selain itu dalam daya tarik wisata ini juga terdapat air terjun yang juga mengeluarkan air panas. Kedua yaitu suasananya yang masih asri dengan hutan bambunya yang masih terjaga serta jauh dari kebisingan dan cocok untuk melepas stress sekaligus merelaksasikan diri dari segala beban pekerjaan yang diterima di kota. Kemudian yang terakhir yaitu masyarakatnya yang tergolong ramah dan terbuka kepada siapa saja yang datang baik itu seputar pengetahuan tentang air panas beserta manfaatnya maupun informasi tentang rencana kedepan dari pengembangan Daya Tarik Wisata Air Panas Angseri.

\subsubsection{Aksessibilitas (Accessibility)}

Jarak lokasi Air Panas Angseri sekitar $40 \mathrm{~km}$ dari Denpasar atau $20 \mathrm{~km}$ dari Kota Tabanan. Perlu waktu sekitar 2 jam perjalanan dari Denpasar melalui jalan utama menuju Bedugul, untuk ke lokasi Air Panas Angseri, ada rute lain ke tempat ini yaitu dari Penebel melalui Jatiluwih ke arah timur laut, dimana rute ini sedikit lebih sulit dibandingkan dengan rute lewat bedugul. Pengembangan yang terus dilakukan dari pihak Pengelola Daya Tarik Wisata Air Panas Angseri masih disekitar daya tarik itu sendiri, Jadi untuk akses yaitu jalan aspal yang berlubang disana-sini selain itu cukup membingungkan juga untuk mencapai lokasi Air Panas Angseri karena harus melewati jalan berkelok-kelok naik turun dan menjumpai dua pertigaan yang tidak ada petunjuk arahnya. Jadi masih mengandalkan penduduk sekitar sebagai penunjuk menuju Air Panas Angseri.

Menurut Putu Setada selaku Pengelola

Daya Tarik Wisata Air Panas Angseri,

"Akses jalan menuju daya tarik wisata yang rusak saat ini sedang berusaha meminta bantuan kepada pemerintah yaitu Pemerintah Kabupaten Tabanan untuk segera memperbaiki jalan atau akses menuju daya tarik wisata ini dan sedang diproses, dari pihak pengelola sendiri saat ini masih terus mengembangkan dan memperbaiki sarana prasarana di sekitaran Daya Tarik Wisata Air Panas Angseri".

\subsubsection{Amenitas (Amenities)}

Sarana dan prasarana yang tersedia didalam daya tarik ini yakni restoran, warungwarung yang dikelola oleh masyarakat lokal, kemudian bilik-bilik pemandian dan dua buah kolam pemandian untuk anak-anak dan dewasa. Untuk akomodasi dulunya ada dan berupa homestay namun karena tidak begitu efektif dalam penggunaannya maka dijadikan bilik pemandian pribadi dan letaknya menyendiri diluar zona kolam dan bilik-bilik yang biasa. Sarana prasarana lainnya seperti tempat parkir yang luas, kamar mandi, ruang ganti, tempat penitipan barang juga tersedia serta jumlah tong sampah disini juga memadai 
sehingga kondisi di daya tarik wisata ini selalu bersih.

\subsubsection{Fasilitas Pendukung (Ancillary Service)}

Fasilitas pendukung yang dimaksud yaitu tersedianya rumah sakit kecil berupa klinik yang ada di Desa Angseri, kemudian terdapat koperasi dimana masyarakat Desa Angseri dapat menyimpan atau meminjam uang, dari segi telekomunikasi terbilang cukup sulit karena daya tarik wisata ini berada di tengah hutan bambu dan berada diketinggian sehingga untuk sarana telekomunikasi seperti sinyal sulit untuk didapat dan untuk kelembagaan Daya Tarik Wisata Air Panas Angseri langsung dari pihak Banjar Angseri sebagai pengurus, pelindung atau penanggungjawab dan juga sebagai pengawas. Untuk pihak luar seperti Dinas Pariwisata juga ambil andil dalam pengawasan yang biasa dipantau setiap bulannya.

\subsection{Tipologi Partisipasi Masyarakat Lokal dalam Pengelolaan DTW}

Pentingnya tipologi partisipasi dalam kegiatan pariwisata yaitu untuk memberi gambaran tentang kondisi aktua baik dari alam, sosial dan budaya yang tumbuh berkembang di suatu daerah dan saling berkaitan satu sama lain mulai dari awal perencanaan suatu daya tarik wisata sampai perkembangannya sampai sekarang.

\subsubsection{Struktur dan Mekanisme Air Panas Angseri}

Terdapat ketua, wakil ketua, sekertaris, bendaharan dan seksi-seksi yang menjalankan Daya Tarik Wisata ini, Putu Setada adalah ketua pengelola diatas daripada struktur organisasi tersebut. Ketua umum berfungsi sebagai pengambil keputusan dalam setiap kebijakan dari pengelolaan daya tarik wisata ini, sekertaris berfungsi dibagian administrasi, bendahara sebagai accounting daya tarik wisata ini. Seksi-seksi yang tersedia sebanyak empat buah, yaitu promosi, usaha, keamanan dan umum. Masing-masing berjumlah tiga orang. Seksi promosi berfungsi untuk mempromosikan daya tarik wisata ini lewat web dan juga pembuatan papan penanda daya tarik wisata, seksi usaha mengkoordinir restoran dan warung-warung yang terdapat di daya tarik wisata, seksi keamanan bertugas menjaga keamanan diarea parkir dan sekitar spot air panas, seksi umum bertugas merekap dan mengarsipkan kegiatan-kegiatan yang berlangsung di daya tarik wisata ini.

Masing-masing dari tiap anggota berasal dari ketiga banjar yang berada di Desa Angseri yaitu, Banjar Tegeh, Banjar Angseri dan Banjar Munduk Lumbung. Sebagian besar dari pihak pengelola maupun staff berasal dari Banjar Angseri karena letaknya lebih dekat dengan daya tarik wisata dan banjar lainnya kebanyakan bekerja sebagai petani, namun dalam struktur pengelolaan Daya Tarik Wisata Air Panas Angseri tetap terdapat anggota yang berasal dari Banjar Tegeh dan Banjar Munduk Lumbung.

\subsubsection{Pengelolaan Air Panas Angseri}

Dalam mengelola Daya Tarik Wisata Air

Panas Angseri diperlukan proses sebagai berikut:

\section{a. Perencanaan.}

Proses prencanaan dari daya tarik ini masih terkendala dari segi akses jalan menuju daya tarik wisata, pihak pengelola masih berusaha untuk segera memperbaiki akses tersebut kepada pihak pemerintah yakni Pemerintah Kabupaten Tabanan, kendala lainnya yaitu kondisi parkir motor yang berbatu sehingga menyulitkan pengguna sepeda motor untuk parkir maupun mengeluarkan kendaraannya, untuk parkir mobil tersedia dua buah lahan parkir yaitu disebelah atas dan didepan plang selamat datang, untuk di parkir mobil sendiri masih berupa tanah sehingga apabila hujan maka banyak genangan air bermunculan, dari pihak pengelola sedang berupaya memperbaiki kondisi parkir untuk kenyamanan wisatawan.

Daya tarik ini terus berkembang pada awal pembentukannya pada tahun 2007 dan saat ini berfokus pada pengembangan saranaprasarana berupa pembuatan kolam baru karena wisatawan yang tiap tahun bertambah membuat pihak pengelola menambah kolam baru sebagai solusi padatnya jumlah wisatawan yang datang.

\section{b. Pengorganisasian}

Pihak-pihak yang turut andil dalam pelaksanaannya lewat masing-masing job desk yang diberikan sesuai bagian yang didapat sesuai dengan struktur pengelolaan yang tercantum. Dari pengamatan yang ditangkap, pengorganisasian yang terjadi telah sesuai dilihat dari cara pihak pengelola mengatur dan menempatkan mereka menurut kemampuan 
dan keahliannya dalam pekerjaan yang sudah direncanakan.

\section{c. Kepemimpinan}

Bentuk kepemimpinan yang dilakukan yaitu bekerjasama dengan pihak dinas pariwisata dalam perencanaan daya tarik wisata kedepannya. Fungsi pemimpin untuk menggerakan organisasi agar berjalan sesuai dengan pembagian kerja masing-masing serta menggerakan seluruh sumber daya yang ada dalam organisasi agar pekerjaan atau kegiatan yang dilakukan bisa berjalan sesuai rencana dan bisa memcapai tujuan.

\section{d. Pengawasan}

Pengawasan yang terjadi yaitu berupa monitoring dari pihak dinas pariwisata yang rutin dilakukan sebanyak tiga kali sebulan, tujuannya yaitu mengawasi apakah gerakan dari Pengelolaan Daya Tarik Wisata Air Panas Angseri sudah sesuai dengan rencana atau belum. Serta mengawasi penggunaan sumber daya dalam organisasi agar bisa terpakai secara efektif dan efisien tanpa ada yang melenceng dari rencana.. Seluruh komponen yang terlibat berperan penting sebagai penggerak daya tarik wisata ini dalam perkembangannya.

\subsubsection{Tipologi Partisipasi Masyarakat Lokal Desa Angseri dalam Pengelolaan Daya Tarik Wisata Air Panas Angseri}

Bentuk partisipasi masyarakat lokal dalam pengelolaan Daya Tarik Wisata Air Panas Angseri berupa peran masyarakat lokal sebagai Host jadi dapat dikatakan masyarakat lokal mengetahui banyak informasi mulai dari kondisi alam, sosial maupun budaya disekitar Desa Angseri, untuk itu peran dalam bentuk partisipasi masyarakat lokal disini sangat penting.

Tipologi Partisipasi berdasarkan Tosun (2006) yaitu Partisipasi Paksaan, Partisipasi Terdorong dan Partisipasi Spontan digunakan untuk mengetahui tiap karakteristik dari Masyarakat Lokal Desa Angseri yang sesuai dalam pengelolaan Daya Tarik Wisata Air Panas Angseri. Berikut adalah tipologi partisipasi yang sesuai di Daya Tarik Wisata Air Panas Angseri: Partisipasi Terdorong, mengapa? karena bersifat Top-down dan Partisipasi Pasif yang pada tahap perencanaan awal yaitu masuknya pihak pemerintah yaitu dinas pariwisata yang memberikan sosialisasi tentang pentingnya terdapat daya tarik wisata di Desa Angseri. Manfaat yang didapat dari kegiatan wisata yaitu meningkatkan perekonomian desa, membuka lapangan pekerjaan dan sebagai bentuk promosi Desa Angseri sendiri.

Masyarakat lokal dapat memberikan pendapat namun belum tentu akan digunakan untuk pengelolaan kedepannya, jadi masyarakat lokal sepenuhnya menunggu keputusan yang disepakati bersama dari pihak pengelola. Dalam Daya Tarik Wisata Air Panas Angseri, masyarakat lokal berperan sebagai pengurus atau pengelola, pegawai atau staff meliputi penjaga tiket masuk daya tarik wisata, pemilik restoran beserta pegawainya, pemilik warung dan tukang kebun. Sebelum terwujudnya daya tarik wisata ini, diadakanlah rapat oleh pihak dinas pariwisata dalam hal mengembangkan sebuah daya tarik wisata dengan mengandalkan potensi alam berupa air panas yang bertempat di Banjar Angseri. Rapat ini dihadiri masyarakat lokal Desa Angseri dan menghadirkan masyarakat dari ketiga banjar yaitu Banjar Angseri, Banjar Tegeh dan Banjar Munduk Lumbung, masyarakat memperoleh hak dalam pembagian keuntungan dimana pada awal pembentukan, banyak yang tidak yakin akan keberhasilan dari pengembangan potensi alam tersebut untuk kegiatan pariwisata, dan awal mulanya terdaftarlah anggota sebanyak 116 orang, setelah itu karena terlalu banyak dan kurang efektif sejalan waktu maka di kurangilah menjadi 38 sampai sekarang. Untuk pembagian hasil, pihak pengelola memberikan keuntungan dari daya tarik wisata sebesar 10\% ke Desa Angseri dan untuk pemerintah berupa pembayaran pajak. Karyawan yang bekerja disini rata-rata memperoleh gaji sebesar 1.500.000 rupiah dan terkadang bisa lebih ataupun kurang tergantung dari ramai tidaknya wisatawan yang berkunjung.

Jadi dapat disimpulkan masyarakat lokal disini bersifat top-down dimana dari awal pembentukan daya tarik wisata ini terdapat sosialisasi yang di berikan pihak dinas pariwisata yang disaksikan langsung oleh masyarakat lokal mulai dari awal pembentukan sampai sekarang, partisipasi masyarakat lokal bersifat pasif dan merupakan partisipasi semu, partisipasi dilakukan secara tidak langsung serta masyarakat mendapat kesempatan mendengarkan dan didengarkan tetapi belum tentu pandangan mereka 
dipertimbangkan oleh pengambil keputusan (tokenisme). Masyarakat mulai memperoleh hak dalam pembagian keuntungan. Terdapat alternatif pilihan dari suatu usulan yang ditawarkan dan terdapat pula feedback dari masyarakat. Dibandingkan kedua tipologi partisipasi yaitu Partisipasi Paksaan yang kriterianya sama-sama bersifat top-down namun terkesan dibuat-buat dan dapat di manipulasi, partisipasinya juga sama-sama tidak langsung,perbedaannya terletak pada tidak adanya pembagian keuntungan bagi masyarakat lokal,masyarakat dihadapkan pada satu pilihan saja dan harus menerima keputusan tersebut serta pihak luar sangat mendominasi disbanding masyarakat lokal itu sendiri dan Partisipasi Spontan yang memiliki perbedaan yang cukup besar dimana partisipasinya bersifat bottom-up dan termasuk partisipasi asli dan aktif, partisipasinya dilakukan secara langsung,masyarakat lokal terlibat dalam pengambilan keputusan serta memiliki kesempatan melakukan perencanaan sendiri,tanggung jawab dan wewenang sepenuhnya.

\section{SIMPULAN DAN SARAN}

\subsection{Simpulan}

Kondisi aktual ditinjau dari komponen produk pariwisata yang terdapat di Daya Tarik Air Panas Angseri berupa terdapatnya atraksi yang memanfaatkan potensi alam yaitu air panas yang mengandung belerang dan pemandangan alam, akses yang masih terkendala dari pihak pengelola namun sedang mencoba mencari pemecahan masalahnya, amenitas yaitu sarana prasarana yang tersedia cukup memadai dan nyaman serta fasilitas pendukung yang cukup lengkap.

Tipologi partisipasi masyarakat lokal dalam pengelolaan Daya Tarik Wisata Air Panas Angseri yaitu partisipasi terdorong, diawali ketika masyarakat lokal diberikan sosialisasi oleh pihak dinas pariwisata dan ikut berperan serta dalam tahap perencanaan daya tarik wisata sampai sekarang diimbangi dengan pembentukan struktur pengelolaan sebagai penggerak dari daya tarik wisata itu sendiri.

\subsection{Saran}

Pariwisata dapat digunakan sebagai sumber pendapatan bagi masyarakat sekitar daya tarik wisata, dalam hal ini sinergi antara lingkungan dan masyarakat lokal dalam perencanaan sebuah kegiatan pariwisata dapat berjalan ke arah yang lebih baik jika diimbangi dengan pengelolaan yang tepat dan disetujui seluruh pihak. Masyarakat lokal Desa Angseri harus berperan dan ikut serta dalam kegiatan pariwisata ini dengan menuangkan ide-ide pengembangan selanjutnya agar lebih baik dengan mencari solusi bagaimana cara menutupi kendala-kendala seperti akses menuju daya tarik yang masih belum di perbaiki, tempat parkir yang kurang layak dan fasilitas tambahan lainnya seperti papan aturan saat melakukan kegiatan di Daya Tarik Air Panas Angseri serta meningkatkan kinerja dari masyarakat lokal dalam mempromosikan daya tarik yang dimiliki.

\section{DAFTAR PUSTAKA}

Anonim. Undang- Undang Republik Indonesia No. 10 Tahun 2009 Tentang Kepariwisataan.

Arikunto, Suharsimi. (1993). Manajemen Penelitian, Jakarta: Rineke Cipta.

James A.F., Stoner. 2006. Management, Palembang: Intermedia Inter.

Moleong, Lexy J. 2012. Metodologi Penelitian Kualitatif. Bandung: PT Remaja Rosdakarya.

Nurdianto, Sigit. 2015. Partisipasi Masyarakat Dalam Pengembangan Desa Wisata (Studi di Desa

Wisata Bleberan, Kecamatan Playen, Kabupaten Gunung Kidul). Yogyakarta: Program Studi Ilmu Kesejahteraan Sosial Fakultas Dakwah dan Komunikasi Universitas Islam Negeri Sunan Kalijaga.

Pitana, I Gde. 1999a. A Community Management dalam Pembangunan Pariwisata (Majalah Ilmiah Pariwisata - Analisis Pariwisata Program Studi Pariwisata Universitas Udayana Volume2 Nomor 2 Tahun 1999e Hal. 75-77).

Sudinata, I Wayan dan I Putu Budiarta. 2013. Kontribusi Pengembangan Ekowisata Taman Sari

Buwana Terhadap Banjar Beng Kaja, Desa Tunjuk, Kabupaten Tabanan. Badung : Jurusan Pariwisata Politeknik Negeri Bali Kampus Bukit Jimbaran,

Bali.

Sastrayuda, Gumelar S. (2010). Concept Resort And Leasure, Strategi Pengembangan Dan Pengelolaan Resort And Leisure.

Sugiyono. 2010. Metode penelitian Pendidikan Pendekatan Kuantitatif, Kualitatif, dan R\&D. Bandung :

Alfabeta.

Sugiyono. 2014. Metode Penelitian Kuantitatif, Kualitatif, dan $R \& D$. Bandung: Alfabeta.

Sunaryo, Bambang. 2013. Kebijakan Pembangunan Destinasi Pariwisata Konsep dan Aplikasinya di Indonesia. Yogyakarta: Gava Media. 
Vol. 5 No 2, 2018

Tosun, Cevat. 2006. Expected Nature of Community Participation in Tourism Development.

Tourism Management, 27,493-504.

Wardiyanta. 2006. Metode Penelitian Pariwisata.

Yogyakarta : Penerbit Andi.

Wicaksono, Purwo Agung. 2013. Efektivitas Program Penataan dan Pengelolaan Obyek Wisata

(Studi Kasus Pariwisata Bahari danPermandian

So'do di Kab. Mamuju). Makasar: Universitas Hasannudin Fakultas Ilmu Sosial dan Politik Jurusan Ilmu Administrasi Program Studi Administrasi.

Yoeti, Oka A. 1985. Pariwisata Budaya Masalah dan Solusinya. Jakarta: PT. Pradnya Paramita.

Sumber Lainnya :

http://baturiti.tabanankab.go.id/profil-desa/desa-angseri 